\title{
Impact of the COVID-19 Pandemic on Gastroenterology Department Activity: The Gastroenterologist's Perspective Nationwide and the Real Impact in a Portuguese Center
}

\author{
Ana Catarina Ribeiro Gomes Rolando Pinho João Carlos Silva \\ Edgar Afecto João P. Correia João Carvalho \\ Department Gastroenterology, Centro Hospitalar Vila Nova de Gaia/Espinho, Vila Nova de Gaia, \\ Porto, Portugal
}

Keywords

COVID-19 pandemic - Gastroenterology department .

Endoscopy $\cdot$ Medical education

\section{Abstract}

Background: Several gastroenterology societies have created recommendations in order to reduce nonessential exposure to the severe acute respiratory syndrome coronavirus 2 (SARS-CoV-2) virus. Our aim is to evaluate the national gastroenterologists' perspective on the impact of COVID-19 and the impact of reorganization of a gastroenterology department during the COVID-19 pandemic. Methods: For the first purpose, an online survey was distributed to gastroenterologists nationwide. For the second purpose, the authors conducted an analysis of some endoscopic procedures performed at the Gastroenterology Department of the Centro Hospitalar Vila Nova de Gaia/Espinho (CHVNG/E) between March 16 and May 8 during the years 2019 and 2020. Results: Sixty-seven gastroenterologists answered our survey. Only $14.9 \%$ were residents and $86.6 \%$ worked in a hospital with

karger@karger.com www.karger.com/pjg

Karger"

GOPEN ACCESS
(C) 2021 Sociedade Portuguesa de Gastrenterologia Published by S. Karger AG, Basel

This is an Open Access article licensed under the Creative Commons Attribution-NonCommercial-4.0 International License (CC BY-NC) (http://www.karger.com/Services/OpenAccessLicense), applicable to the online version of the article only. Usage and distribution for commercial purposes requires written permission.
COVID-19 patients, with $16.4 \%$ assigned to assist those patients. All of the departments suffered modifications. Ninety percent of the residents affirmed that their activity had changed. Ninety-four percent declared having nonessential endoscopic procedures postponed, and $85.1 \%$ maintained in-person medical visits, $88.1 \%$ were already having remote consultations, and $11.9 \%$ did not have any clinical visit. In our gastroenterology unit, the number of endoscopic procedures decreased by $73.1 \%$ from 2019 to 2020. In 2020, the proportion of urgent procedures was higher compared to 2019. Conclusion: The advent of COVID-19 has led to important changes in gastroenterology activities in Portugal, and national gastroenterology units are complying with the recommendations. Furthermore, Portuguese gastroenterologists believed that the decrease in endoscopic activity can compromise residents' education and training. The gastroenterology department at CHVNG/E has shown a significant reduction in the number of endoscopic procedures.

(c) 2021 Sociedade Portuguesa de Gastrenterologia Published by S. Karger AG, Basel

Correspondence to:

Ana Catarina Ribeiro Gomes, catarina.rib.gomes@gmail.com 
Impacto da pandemia COVID-19 na atividade nos departamentos de gastrenterologia - a perspectiva nacional do gastrenterologista e o real impacto num centro Português

\section{Palavras Chave}

Pandemia COVID-19 · Serviços de gastroenterologia . Endoscopia · Formação médica

\section{Resumo}

Introdução: As sociedades de Gastroenterologia criaram recomendações de modo a reduzir a exposição não necessária ao vírus da síndrome respiratória aguda grave (SARS-CoV-2). O nosso objetivo é avaliar a perspectiva nacional dos gastroenterologistas sobre o impacto da $\mathrm{CO}$ VID-19 e avaliar o impacto da reorganização do nosso serviço de Gastroenterologia durante a pandemia. Métodos: Para o $1^{\circ}$ objetivo, um inquérito online foi disponibilizado aos gastroenterologistas de todo o país. Para o $2^{\circ}$ objetivo, os autores realizaram uma análise dos procedimentos endoscópicos do serviço de Gastroenterologia do Centro Hospitalar Vila Nova de Gaia/Espinho (CHVNG/E) entre 16 de Março e 8 de Maio durante os anos de 2019 e 2020. Resultados: 67 gastroenterologistas responderam o inquérito. Destes, $14.9 \%$ eram internos. $86.6 \%$ trabalharam num hospital com doentes com COVID-19, e $16.4 \%$ dos médicos prestavam cuidados a esses doentes. Todos os departamentos sofreram alterações. $90 \%$ dos internos referiram que a atividade tinha sido alterada. $94 \%$ dos médicos afirmaram que os procedimentos endoscópicos não-essenciais foram adiados. $85.1 \%$ mantinham algumas consultas médicas presenciais, $88.1 \%$ estavam a realizar consultas não presenciais, e $11.9 \%$ não tinham nenhum tipo de consulta. No nosso serviço, o número de procedimentos endoscópicos diminui em 73.1\% de 2019 para 2020. Em 2020, a proporção de procedimentos endoscópicos de urgência foi superior em relação a 2019. Conclusão: A pandemia da COVID-19 conduziu a alterações importantes dentro das atividades da Gastroenterologia em Portugal, e os serviços de Gastroenterologia mostraram cumprir as recomendações. Além disso, os gastroenterologistas portugueses acreditam que a diminuição da atividade endoscópica dos internos pode comprometer a sua futura formação. O serviço de gastroenterologia do $\mathrm{CHVNG/E} \mathrm{mostrou} \mathrm{uma} \mathrm{redução} \mathrm{significativa}$ do número de procedimentos endoscópicos.

(c) 2021 Sociedade Portuguesa de Gastrenterologia Publicado por S. Karger AG, Basel

\section{Introduction}

On January 30, 2020, COVID-19 was declared a Public Health Emergency of International Concern according to the World Health Organization, and it was declared a global pandemic on March 11, 2020 [1].

Addressing the current public health problem due to COVID-19, the government of Portugal declared a state of emergency on March 18, 2020 [2].

Once the politics of social distancing measures and quarantine actions had been implemented and following the general strategic intent expressed by governmental organizations to reduce any nonessential exposure to the severe acute respiratory syndrome coronavirus 2 (SARS-CoV-2) virus, on March 13, 2020, the Portuguese Society of Digestive Endoscopy (SPED) announced that all endoscopic procedures considered nonessential should be canceled or postponed until the spread of the virus is controlled [3]. Subsequently, in association with the Portuguese Society of Gastroenterology (SPG) and the National Medical Board, these societies updated their recommendations for national endoscopy units [4].

On May 4, the Portuguese government declared the transition from a state of emergency to a phase of calamity, which allowed resumption of some activities according to the Portuguese gastroenterology societies and the National Medical Board [5].

The Gastroenterology Department of the Centro Hospitalar Vila Nova de Gaia/Espinho (CHVNG/E) was forced to undergo dynamic changes, and elective procedures were canceled from March 13 until May 8. Despite these recommendations, some elective procedures were performed in patients in whom postponement could change the prognosis in a 3-month period.

The purposes of this paper are to evaluate: (1) the national gastroenterologists' perspective of the impact of COVID-19 on the gastroenterology activity and education and (2) the real impact of reorganization of a Portuguese gastroenterology department during the COVID-19 pandemic and to compare it with the homologous period of 2019 .

\section{Methods}

For the first purpose, a survey of 32 questions (online suppl. material; see www.karger.com/doi/10.1159/000516962 for all online suppl material) was created using an online platform (Google forms) and distributed to gastroenterologists nationwide via e-mail through the National Center of Data Registration in 
Fig. 1. Residents' activities modified due to the COVID-19 outbreak according to the interns.

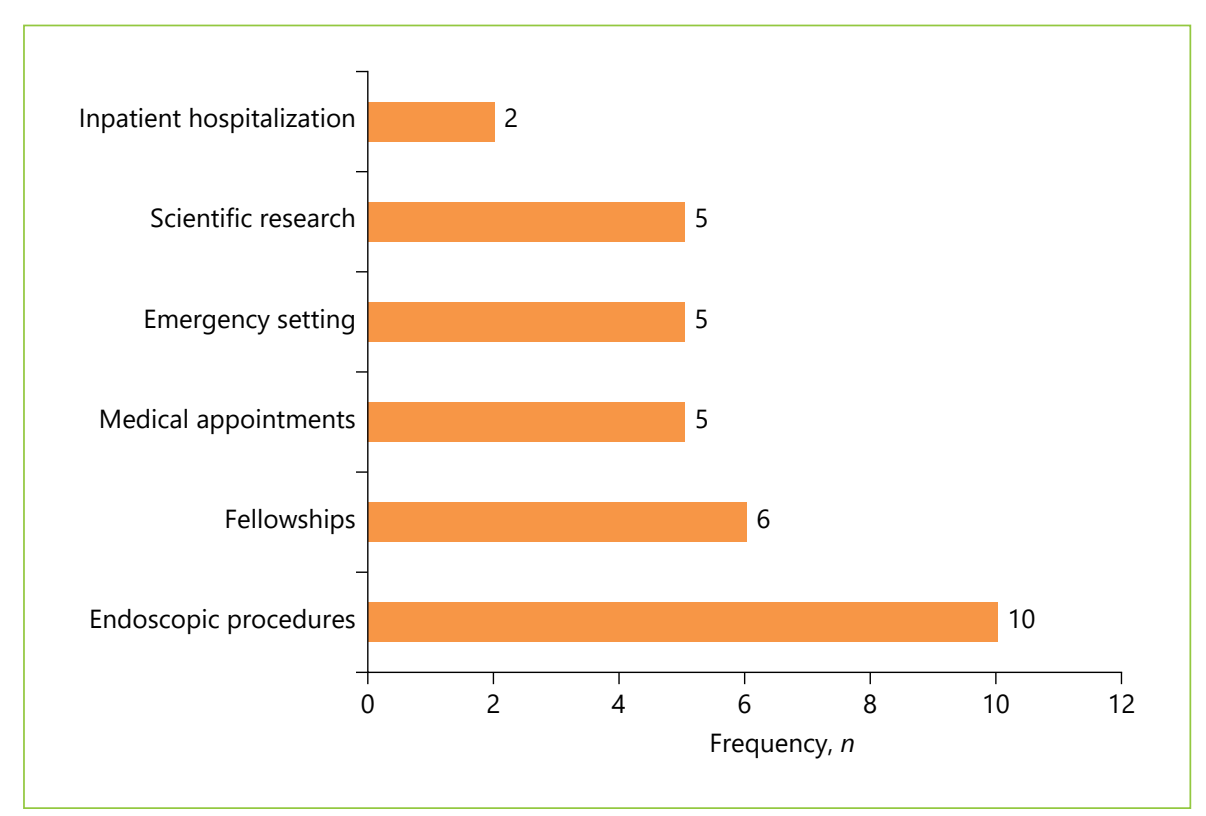

Gastroenterology (CEREGA), which belongs to the Portuguese Society of Gastroenterology.

For the second purpose the authors conducted a retrospective consecutive analysis of some endoscopic procedures performed in the Gastroenterology Department of CHVNG/E between March 16 and May 8 during the years 2019 and 2020. The following procedures were analyzed and compared: upper gastrointestinal (GI) endoscopies, colonoscopies, capsule endoscopies, and endoscopic retrograde cholangiopancreatography procedures. All of the procedures were collected and divided into elective and urgent GI cases.

Statistical Package for Social Sciences (SPSS) 20 was used for data compilation, preparation, and analysis. The groups were compared using a two-tailed Student $t$ test (continuous parametric variables), the Mann-Whitney $U$ test (continuous nonparametric variables), and the Pearson $\chi^{2}$ test (categorical variables). $p<0.05$ was considered statistically significant.

\section{Results}

\section{National Survey}

A total of 67 gastroenterologists answered our survey between April 15 and May 5, 2020, 53.7\% of whom were female $(n=36)$ and $94 \%(n=63)$ of whom were $<65$ years old. When analyzing the age range, people aged 55-65 years were the most prevalent group $(25.4 \%, n=17$; online suppl. Fig. 1). When analyzing the gastroenterology department locations, $32.8 \%$ of the doctors were from Lisbon, 22.4\% were from Oporto, and 9\% were from Coimbra (online suppl. Fig. 2). The great majority of the hospitals belong to the public health system $(73.1 \%, n=$
49; online suppl. Fig. 3). Only $14.9 \%(n=10)$ were residents (online suppl. Fig. 4).

In our survey, $86.6 \%(n=58)$ of the doctors worked in a hospital with COVID-19 patients. All of the departments had suffered modifications during the COVID-19 outbreak.

Only $16.4 \%$ of the doctors $(n=11)$ had performed a reverse transcription polymerase chain reaction (RTPCR) SARS-CoV-2 screening, and $18.2 \%$ of them had a positive test $(n=2)$.

\section{Inpatient Hospitalization}

Regarding inpatient hospitalization, 35.8\% $(n=24)$ of the doctors reported that the number of available beds had decreased.

Residence Education and Training

Of the 10 residents who answered this survey, almost all $(90 \%, n=9)$ referred that their activity had changed due to the outbreak. The main activities that suffered modifications were endoscopic procedures and fellowships (Fig. 1).

Of all of the doctors who answered the survey, 23.9\% $(n=16)$ reported that the residents in their department could not perform endoscopic procedures due to rationing of personal protective equipment (PPE) and in order to limit the spread of the virus.

Overall, $71.6 \%(n=48)$ of the gastroenterologists believed that the COVID-19 situation could influence the 

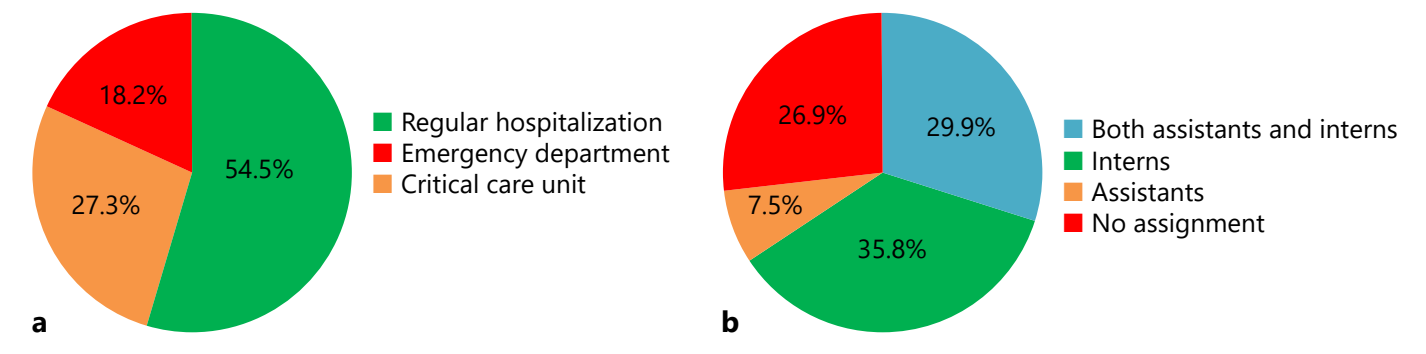

Fig. 2. a Doctors' distribution to assisting COVID-19 patients. b Medical career of the doctors assigned to assisting COVID-19 patients.

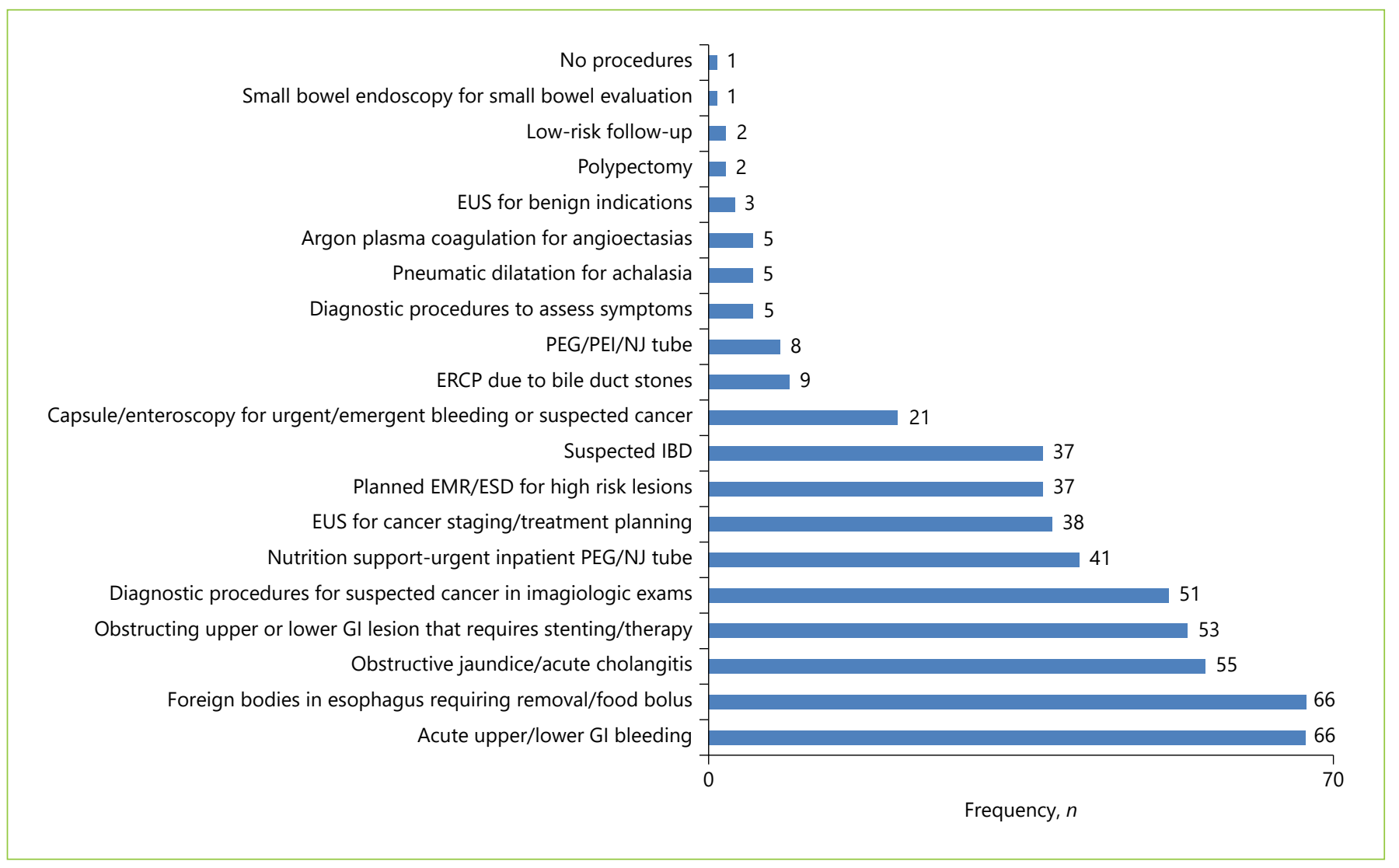

Fig. 3. Procedures performed in the endoscopy units during the COVID-19 outbreak according to each doctor. Low-risk follow-up procedures: esophagitis healing, gastric ulcer healing, follow-up EMR/ESD. Endoscopic ultrasound (EUS) for benign indications: biliary dilatation, possible stones, submucosal lesions, and pancreatic cysts without high-risk features.

residents' education and training. Furthermore, 64.2\% $(n=43)$ considered that the gastroenterology internship should be temporarily suspended and possibly extended later on.
Doctors' Allocation during the COVID-19 Outbreak Concerning allocation during the outbreak, $71.6 \%$ ( $n$ $=48$ ) of the doctors were organized into rotating teams, with a median of 5 doctors per week (IQR 3-7). 


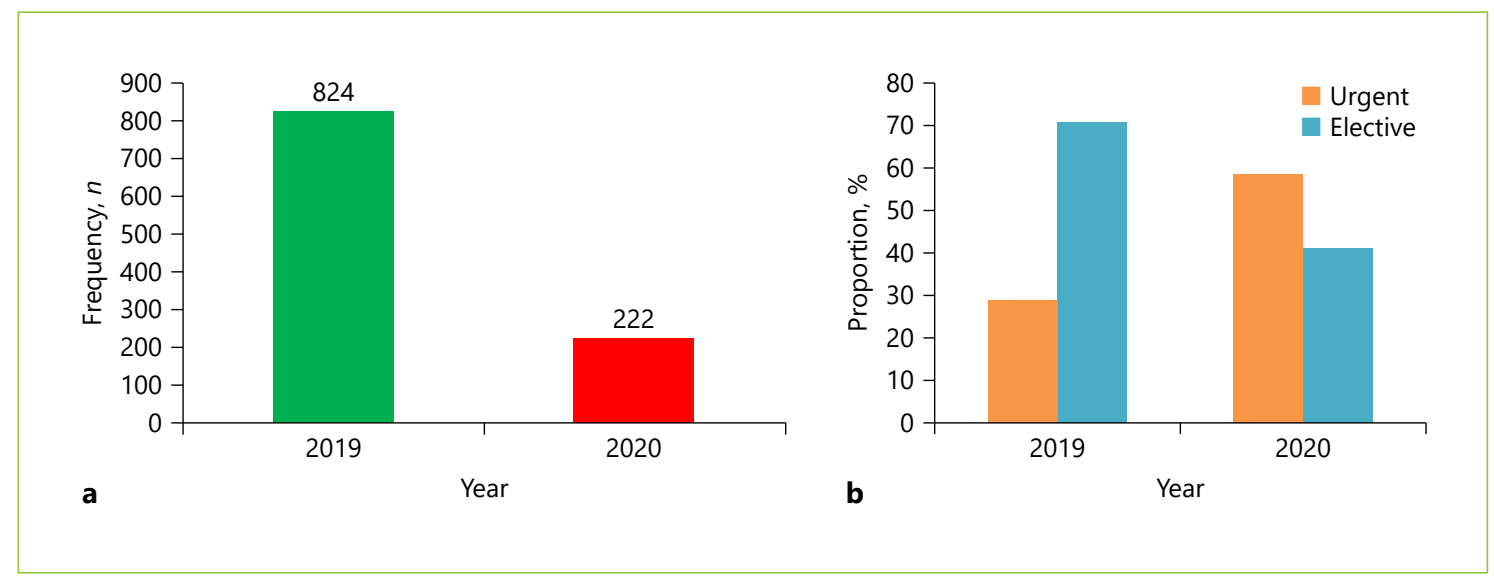

Fig. 4. a Total number of endoscopic procedures performed between March 16 and May 8 in CHVNG/E during 2019 and 2020. b Urgent/elective procedures in 2019 or 2020. $p<0.001$.

In the survey, $16.4 \%(n=11)$ of the doctors were assigned to the assistance of COVID-19 patients, with the majority of these being interns (63.6\%). Of those, $54.5 \%$ $(n=6)$ worked in regular hospitalization floors, $27.3 \%$ $(n=3)$ worked in emergency departments, and $18.2 \%$ $(n=2)$ worked in a critical care unit (Fig. 2a).

Of the participants, $29.9 \%(n=20)$ reported that both assistants and interns in their departments were assigned to work with COVID-19 patients (Fig. 2b), and 35.8\% $(n=24)$ referred that only residents were assigned to this task (Fig. 2b).

\section{Endoscopic Procedures}

The majority $(94 \%, n=63)$ declared having nonessential endoscopic procedures postponed, except for procedures in which the patient's prognosis could change in a 3-month period. Due to the outbreak, only urgent/emergent procedures were being performed according to $38.8 \%(n=26)$ of our participants. Overall, the procedures that continued to be carried out were for acute upper/lower GI bleeding, for foreign bodies in the esophagus requiring removal/food bolus, and for obstructive jaundice/acute cholangitis, with a frequency of 66,66 , and 55 answers, respectively. On the other hand, few doctors $(<3)$ answered that procedures for routine small bowel endoscopy, low-risk follow-up endoscopies, and polypectomies were being performed (Fig. 3).

According to the medical staff of this survey, a median of 20 endoscopic procedures a week were performed before the COVID-19 outbreak (IQR 15-42; online suppl. Fig. 5a), and after the implementation of COVID-19 re- strictions this number declined significantly to a median of 3 endoscopic procedures a week (IQR $0-6 ; p<0.001$; online suppl. Fig. 5b).

\section{Medical Visits}

Most of the doctors $(82.1 \% ; n=55)$ stated that in-person medical visits were maintained. However, $88.1 \%(n=$ $59)$ also had remote appointments. Only $11.9 \%(n=8) \mathrm{did}$ not have any clinical visits during the COVID-19 pandemic. The majority of the clinicians were worried about the follow-up/management of their patients, and $44.8 \%$ $(n=30)$ of them felt very or extremely worried (online suppl. Fig. 6).

Of the doctors with inflammatory bowel disease patients $(n=45)$, only $1(2.2 \%)$ reported that his patients had an immunosuppression (IS) or biologic treatment suspended. Of the 43 doctors with patients with refractory ascites, none reported having a patient with a cancelled therapeutic paracentesis. Of the 24 doctors with patients with viral hepatitis, only $20.8 \%(n=5)$ had the initiation of treatment postponed.

\section{Impact of COVID-19 in the CHVNG/E Gastroenterology Department}

In 2019, between March 16 and May 8 (54 days), 824 procedures were performed in our department, compared to the 222 procedures in the homologous period of 2020 (Fig. 4). In 2019 a total of $54.1 \%(n=446)$ were male, with a mean age of $63 \pm 17$ years, and in $202059.5 \%$ ( $n=$ 132 ) were male, with a mean age of $65.2 \pm 18.6$ years. These demographic data did not differ between the 2 periods (sex: $p=0.16$; age: $p=0.10$ ). 


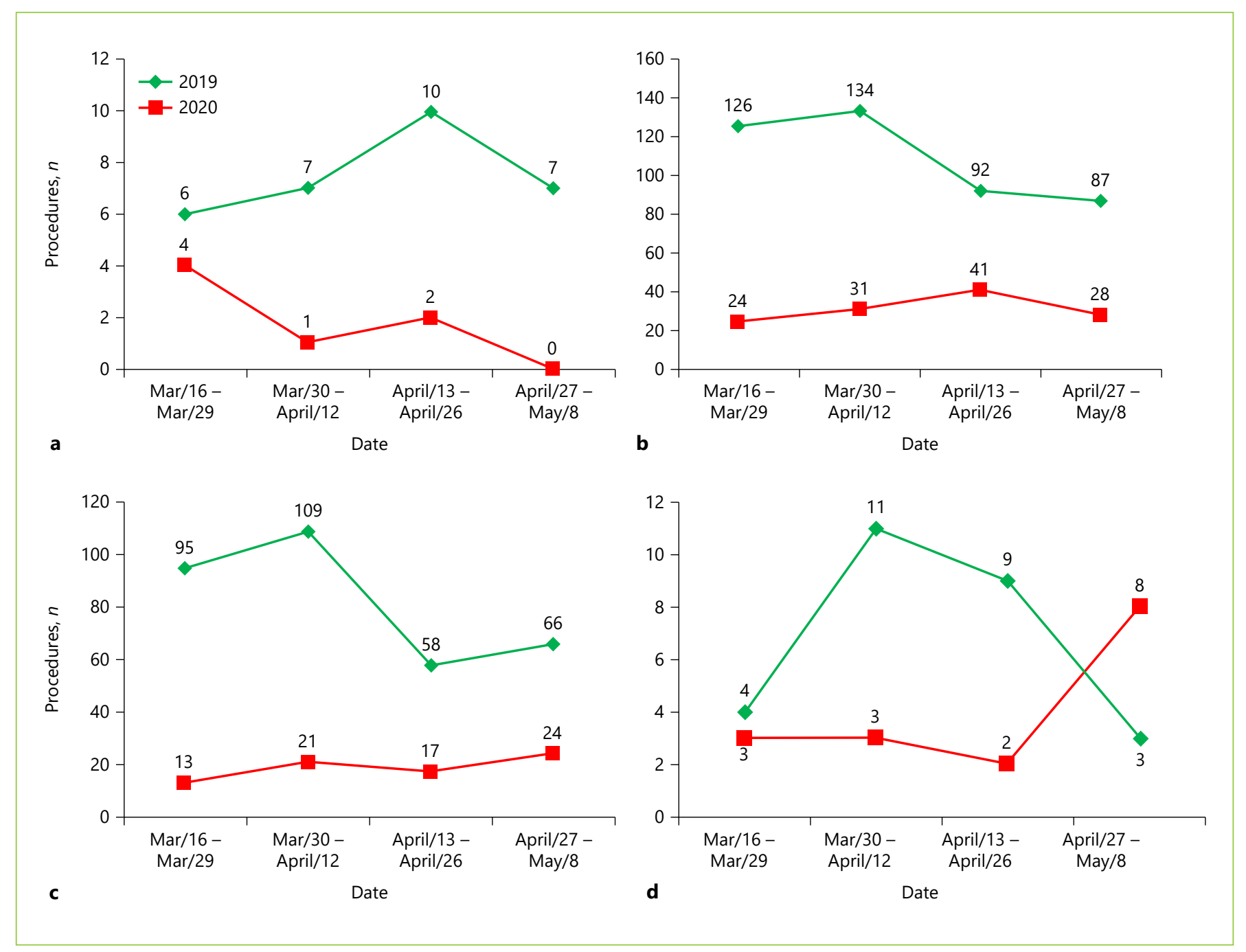

Fig. 5. Number of procedures performed between March 16 and May 8 in 2019 and 2020. a Capsule endoscopy. b Upper endoscopy. c Colonoscopy. d ERCP.

In 2020, the proportion of urgent procedures was higher in comparison with the homologous period in 2019 (urgent cases in 2019: $29 \%$ vs. 2020: 58.6\%; $p<$ $0.001)$.

\section{Capsule Endoscopy}

In 2019, thirty capsule endoscopies were performed in 54 days (Fig. 5a); 86.7\% $(n=26)$ were elective and $13.3 \%$ $(n=4)$ were urgent. In 2020, seven capsule endoscopies were performed (Fig. 5a); $71.4 \%(n=5)$ were elective and $28.6 \%(n=2)$ were urgent, and the proportion of urgent/ elective cases was not statistically different from that in 2019 (2019: $13.3 \%$ vs. $2020: 28.6 \%$; $p=0.33$ ).

\section{Upper Endoscopy}

In 2019 during the 54-day period, 439 upper endoscopies were performed (Fig. 5 b); $61.7 \%(n=271)$ were elective and $38.3 \%(n=168)$ were urgent. Conversely, in the 2020 period 124 upper endoscopies were performed (Fig. 5b); 59.7\% $(n=74)$ were done in an urgent setting and $40.3 \%(n=50)$ were done in an elective one. There was a higher ratio of urgent procedures in 2020 compared to 2019 (2019: $38.3 \%$ vs. $2020: 59.7 \%$; $p<0.001$; online suppl. Fig. 7a, b).

\section{Colonoscopy}

In 2019, three hundred twenty-eight colonoscopies were performed at our center during the 54-day period 
(Fig. $5 c), 80.2 \%(n=263)$ of which were elective and $19.8 \%(n=65)$ of which were urgent. In 2020, 75 colonoscopies were performed (Fig. 5 c); $68 \%(n=51)$ were urgent and $32 \%(n=24)$ were elective. As with upper endoscopies, urgent cases were more prevalent in 2020 (2019: 19.8\% vs. 2020: $68 \%$; $p<0.001$; online suppl. Fig. $7 c$, d).

Endoscopic Retrograde Cholangiopancreatography

In 2019, between March 16 and May 8, twenty-seven endoscopic retrograde cholangiopancreatographies (ERCP) were performed at our department (Fig. 5d); only $7.4 \%$ were done in an urgent setting $(n=2)$. On the other hand, in the homologous period of 2020, only 16 ERCP were completed (Fig. $5 \mathrm{~d}$ ); there was a higher proportion of urgent procedures, although this was not statistically significant $(18.8 \%, n=3 ; p=0.26)$.

\section{Discussion}

Gastroenterology services suffered major consequences due to rearrangements in hospital activities due to COVID-19. The current analysis allowed the assessment of gastroenterologists' perspective in Portugal and observation of how these modifications influenced the real number of main endoscopic procedures usually performed in our gastroenterology department at CHVNG/E.

Overall, 67 gastroenterologists answered our survey; most were 55-65 years-old and perhaps doctors with accumulated clinical experience who feel more restless due to the current situation. The low participation could be related to the fact that the survey was undertaken during a challenging part of the outbreak and some physicians did not have the time or energy to answer a survey. In addition, the majority of the doctors belonged to the national public health system, which could be related to the high number of gastroenterology departments in the public system in Portugal. Only $14.9 \%$ of the doctors were residents, reflecting the average age of the surveyed population. The most populous areas of Portugal, i.e., Lisbon and Oporto, were adequately represented, with 32.8 and $22.4 \%$ of the total responding areas, respectively.

All of the hospitals had suffered modifications due to the outbreak and almost all of the participants (86.6\%) referred to work at an institution admitting COVID-19 patients, similar to the Italian reality ( $86.9 \%$ in 1 survey) [6]. In Portugal, from 2013 until 2019, the minimum and maximum annual bed occupancy rates were 85.7 and $101 \%$ [7], respectively, and in the same period this rate in CHVNG ranged from 88.4 to $93.7 \%$ [8]. Unfortunately, hospitals are designed for average patient loads and not epidemics, and the effective extra capacity to absorb patients with COVID-19 is low. Additionally, the treatment for patients with COVID-19 is long (a mean of $\sim 13$ days), conditioning the number of new patients who can be accommodated per day during an extended outbreak [9]. Rationing decisions have to be made that extend well beyond patients with COVID-19 and, as revealed in this survey, around $40 \%$ of participants reported that the number of beds in their hospitals for regular inpatient admission had decreased.

Despite the increasing calls for universal screening of healthcare workers for SARS-CoV-2, only $16.4 \%$ of the doctors who answered the survey have been screened, and $18.2 \%$ of them tested positive. These data are consistent with previous reports regarding screening [6] and the percentage of positive tests among healthcare workers [10]. Universal staff testing presents some advantages, as it could mitigate workforce depletion due to self-isolation of symptomatic staff since a substantial proportion of these workers are not infected. In addition, it allows early identification and isolation of asymptomatic SARS-CoV2-positive workers $[11,12]$.

The vast majority (90\%) of the survey's residents reported a change in daily activity in their units during the outbreak, similar to what was already demonstrated in an international survey [6]. According to $65.7 \%$ of the participants, residents were more frequently diverted to $\mathrm{CO}$ VID-19 units; this is a higher proportion compared to simultaneous international data [6]. Many doctors (71.8\%) believed that this outbreak could impact the residents' education and training, and some participants (64.2\%) agreed to address this gap in training by extending the training period. The main reason for this gap is, according to the residents, the reduction of trainees' involvement in endoscopic procedures due to rationing of PPE and in order to limit the spread of the virus. These data are in line with the concerns previously described by residents at an international [6] and national level [13].

Contrary to Italian reports [6], in this Portuguese survey fewer participants (16.4\%) were assigned to COVID-19 units, and of those assigned more than half worked in regular hospitalization floors where no extensive knowledge about intensive cardiorespiratory care management is needed. Nevertheless, $71.6 \%$ of the doctors mentioned that the GI team was organized into rotating teams, which has been previously associated with improvements in workforce preservation [14].

Almost all of the doctors (94\%) declared that nonessential endoscopic procedures had been postponed, paral- 
lel to what was witnessed in other countries in order to protect patients and endoscopy unit personnel [15]. Furthermore, almost $40 \%$ of the doctors reported that only urgent/emergent procedures were being performed, which could ultimately jeopardize the benefit of endoscopy in digestive cancers diagnosed and treated by GI endoscopy [16]. Overall, the procedures performed during the outbreak were mostly related to the main common indications in an urgent setting [17], such as acute upper/ lower GI bleeding, foreign bodies in the esophagus requiring removal, and obstructive jaundice/acute cholangitis. Though not included in an urgent setting, diagnostic procedures for suspected cancer in imagiologic tests were also well represented, and this could be related to the fact that this work-up could change the patient's prognosis in a 3-month period [18]. At our department in CHVNG/E, between March 16 and May 8, the number of endoscopic procedures decreased by $73.1 \%$ from 2019 to 2020 (2019: 824 vs. $2020: 222$ ). In addition, the ratio of urgent to elective procedures was significantly different between both years, which shows the real influence of COVID-19 arrangements in the normal routine of endoscopic units [15, $19,20]$. Elective procedures have been the most impaired by the pandemic. This will certainly lead to a large overload of rescheduled procedures when the pandemic is over, including endoscopy for postpolypectomy surveillance [21], colorectal cancer screening [22], or surveillance of dysplasia in inflammatory bowel disease [23].

Although the number of patients coming to hospitals has been limited, $82.1 \%$ of the doctors still maintained some in-person medical visits. However, $88.1 \%$ referred to adoption of remote consultations in order to guarantee the ordinary follow-up, as was recommended by Portuguese societies [4]. Nevertheless, the majority of the clinicians worried about their patients. In almost all GI divisions chronic outpatient treatments were continued. With regard to treatment initiation in viral hepatitis, around $21 \%$ of the doctors of these patients had preferred to postpone initiation, which could be considered in some patients [24].

This is a transversal study about the effects of the COVID pandemic on gastroenterology units and it has allowed us to see Portuguese gastroenterologists' perspective and evaluate the real impact of the outbreak in a tertiary center. Nonetheless, there are some limitations to consider. First, the representativeness of Portuguese gastroenterologists was limited by the small number of respondents. Second, the impact on endoscopic activity was analyzed in a single center and concerning only some procedures.
In conclusion, the advent of the COVID-19 outbreak has led to profound changes in gastroenterology activities in Portugal, which is in line with some previous published data. According to our data, it is clear that the majority of Portuguese gastroenterology departments are complying with the standards put forth by different societies, both national and international. Concerning the residents, the decrease in endoscopic activity can compromise their training as gastroenterologists, and the unanimous opinion is that internship should be extended.

At our gastroenterology unit there was a significant reduction in the number of endoscopic procedures performed during the period between 2019 and 2020, mainly in the elective setting, and this could have a long-term impact which is unfortunately difficult to predict at this time.

\section{Acknowledgment}

The authors would like to thank the CEREGA group and SPG for their support and distribution of the survey to the medical gastroenterology community.

\section{Statement of Ethics}

The subjects provided written informed consent, and the study protocol was approved by the local ethics committee on July 23, 2020.

The research was conducted ethically in accordance with the Declaration of Helsinki (2014) [25].

\section{Conflict of Interest Statement}

The authors have no conflict of interests to declare.

Funding Sources

No funding was received for this study.

\section{Author Contributions}

A.C. Ribeiro Gomes and R. Pinho: study conception and design. A.C. Ribeiro Gomes and E. Afecto: data collection and analysis and interpretation of the results. A.C. Ribeiro Gomes, R. Pinho, and J.P. Correia: preparation of this paper. All of the authors reviewed the results and approved the final version of this work. 


\section{References}

1 WHO announces COVID-19 outbreak a pandemic. 2020. Geneva: WHO.

2 Diário da República Portuguesa No55 No. 55 DdRP: Decreto do Presidente da República No. 14-A/2020. 2020. Lisboa.

3 Sociedade Portuguesa de Endoscopia Digestiva. 2020, Lisboa.

4 Comunicado conjunto das Sociedades Portuguesas de Endoscopia Digestiva (SPED), Gastrenterologia (SPG) e Coloproctologia (SPCP) e do Colégio da Especialidade de Gastrenterologia da Ordem dos Médicos. 2020, Lisboa.

5 Comunicado conjunto do Colégio da Especialidade de Gastrenterologia da Ordem dos Médicos e das Sociedades Portuguesas de Endoscopia Digestiva (SPED) e Gastrenterologia (SPG). 2020, Lisboa.

6 Marasco G, Nardone OM, Maida M, Boskoski I, Pastorelli L, Scaldaferri F, Italian Association of Young Gastroenterologists and Endoscopists. Impact of COVID-19 outbreak on clinical practice and training of young gastroenterologists: A European survey. Dig Liver Dis. 2020 Dec;52(12):1396-1402.

7 Serviço Nacional de Saúde. Taxa de Ocupação Hospitalar Nacional, Gov., Lisboa, 2020.

8 Serviço Nacional de Saúde. Taxa de Ocupação Hospitalar, Centro Hospitalar Vila Nova de Gaia/Espinho, Lisboa, 2020.

9 Guan WJ, Ni ZY, Hu Y, Liang WH, Ou CQ, He JX, et al.; China Medical Treatment Expert Group for Covid-19. Clinical Characteristics of Coronavirus Disease 2019 in China. N Engl J Med. 2020 Apr;382(18):1708-20.

10 Khalil A, Hill R, Ladhani S, Pattisson K, O'Brien P. COVID-19 screening of healthcare workers in a London maternity hospital. Lancet Infect Dis. 2021 Jan;21(1):23-4.

11 Black JR, Bailey C, Przewrocka J, Dijkstra KK, Swanton C. COVID-19: the case for health- care worker screening to prevent hospital transmission. Lancet. 2020 May;395(10234): 1418-20.

12 Treibel TA, Manisty C, Burton M, McKnight Á, Lambourne J, Augusto JB, et al. COVID-19: PCR screening of asymptomatic health-care workers at London hospital. Lancet. 2020 May;395(10237):1608-10.

13 Brandão C, Gorjão R. Training Program in Gastroenterology: How Can It Survive the Pandemic? GE Port J Gastroenterol. 2020 Jul;27(4):224-6.

14 Kluger DM, Aizenbud Y, Jaffe A, Parisi F, Aizenbud L, Minsky-Fenick E, et al. Impact of healthcare worker shift scheduling on workforce preservation during the COVID-19 pandemic. Infect Control Hosp Epidemiol. 2020 Dec;41(12):1443-5.

15 Maida M, Sferrazza S, Savarino E, Ricciardiello L, Repici A, Morisco F, et al. Impact of the COVID-19 pandemic on Gastroenterology Divisions in Italy: a national survey. Dig Liver Dis. 2020 Aug;52(8):808-15.

16 Gralnek IM, Hassan C, Dinis-Ribeiro M. COVID-19 and endoscopy: implications for healthcare and digestive cancer screening. Nat Rev Gastroenterol Hepatol. 2020 Aug; 17(8):444-6.

17 Apel D, Riemann JF: Emergency endoscopy. Can J Gastroenterol. 2000 Mar;14(3):199203.

18 Gralnek IM, Hassan C, Beilenhoff U, Antonelli G, Ebigbo A, Pellisè M, et al. ESGE and ESGENA Position Statement on gastrointestinal endoscopy and the COVID-19 pandemic. Endoscopy. 2020 Jun;52(6):483-90.

19 Alboraie M, Piscoya A, Tran QT, Mendelsohn RB, Butt AS, Lenz L, et al. The global impact of COVID-19 on gastrointestinal endoscopy units: An international survey of endosco- pists. Arab J Gastroenterol. 2020 Sep;21(3): 156-61.

20 Mahadev S, Aroniadis OC, Barraza LH, Agarunov E, Smith MS, Goodman AJ, et al.; on behalf of NYSGE research committee. Gastrointestinal endoscopy during the coronavirus pandemic in the New York area: results from a multi-institutional survey. Endosc Int Open. 2020 Dec;8(12):E1865-71.

21 Hassan C, Quintero E, Dumonceau JM, Regula J, Brandão C, Chaussade S, et al.; European Society of Gastrointestinal Endoscopy. Post-polypectomy colonoscopy surveillance: European Society of Gastrointestinal Endoscopy (ESGE) Guideline. Endoscopy. 2013 Oct;45(10):842-51.

22 Rex DK, Boland CR, Dominitz JA, Giardiello FM, Johnson DA, Kaltenbach $\mathrm{T}$, et al. Colorectal Cancer Screening: Recommendations for Physicians and Patients From the U.S. Multi-Society Task Force on Colorectal Cancer. Gastroenterology. 2017 Jul;153(1): 307-23.

23 Annese V, Daperno M, Rutter MD, Amiot A, Bossuyt P, East J, et al.; European Crohn's and Colitis Organisation. European evidence based consensus for endoscopy in inflammatory bowel disease. J Crohn's Colitis. 2013 Dec;7(12):982-1018.

24 Crespo J, Andrade R, Alberca de Las Parras F, Balaguer F, Barreiro-de Acosta M, Bujanda L, et al. Resumption of activity in gastroenterology departments. Recommendations by SEPD, AEEH, GETECCU and AEG. Gastroenterol Hepatol. 2020 Jun - Jul;43(6):332-47.

25 General Assembly of the World Medical Association. World Medical Association Declaration of Helsinki: ethical principles for medical research involving human subjects. J Am Coll Dent. 2014;81(3):14-8. 